\title{
Verbo fálico: sobre o erotismo divino na canção Sobre todas as coisas de Chico Buarque e Edu Lobo
}

\author{
Márcio Ronei Cravo Soares (Rede Inconfidência de Rádio, Belo Horizonte, MG) \\ marcioronei@yahoo.com.br
}

\begin{abstract}
Resumo: Este artigo pretende realizar uma leitura interpretativa da canção Sobre todas as coisas, composta por Chico Buarque e Edu Lobo, gravada originalmente no LP O grande circo místico (1983). A partir da ideia de canção como espaço que conjuga os textos verbal (a letra) e musical (melodia, harmonia e ritmo), vistos em relação de mútua correspondência, interessa-nos tentar perceber de que modo aspectos daqueles dois textos estão correspondidos e contribuem para a construção discursiva do sentimento amoroso, cenário afetivo em que um erótico eu-lírico entoa o canto sensual de sua vontade. Devido às relações pressentidas entre um discurso de fundo religioso-cristão e certa carga de sensualidade em Sobre todas as coisas, guardaremos, também, nossa leitura do poema $O$ grande circo místico, publicado por Jorge de Lima em A túnica inconsútil (1938), além de referências ao compêndio Bíblia Sagrada.
\end{abstract}

Palavras-chave: música popular brasileira; análise verbo-musical; Chico Buarque e Edu Lobo.

\section{Phallic word: on divine eroticism in the song Sobre todas as coisas (About everything) by Chico Buarque and Edu Lobo}

Abstract: This article aims at performing an interpretive analysis of the song Sobre Todas as Coisas (About everything) by Brazilian Chico Buarque and Edu Lobo, originally recorded on the long play O Grande Circo Místico (1983). Departing from the idea of the song as a space that combines verbal text (the lyrics) and musical text (melody, harmony and rhythm) seen in mutual relation, I try to understand the correspondences between these two texts and contribute to the discursive construction of the feeling of love, that is the affection scenario in which an erotic narrator sings the sensual chant of his desire. Due to the relationship perceived between a Christian-based speech and some sensuality in the song Sobre Todas as Coisas, we also put in perspective the poem 0 Grande Circo Mistico, published by Brazilian Jorge de Lima on A Túnica Inconsútil (1938), as well as references from the Holy Bible.

Keywords: Brazilian popular music; verbal-musical analysis; Chico Buarque and Edu Lobo.

\section{Sobre o objeto de estudo}

Este artigo apresenta, como contexto temático, a produção musical do cancioneiro popular brasileiro. Aproximarnos-emos do que, tradicionalmente, é identificado pela sigla MPB, correspondente da expressão Música Popular Brasileira. Antes mesmo de definirmos nosso objeto de estudo, cumpre delimitar o horizonte conceitual daquela expressão a ser considerado por nós.

Em texto publicado na revista Debates, a pesquisadora Martha Tupinambá de Ulhôa situa o uso da sigla MPB a partir de um contexto midiático. Examinando a questão, diz a estudiosa:
Com a consolidação dos meios de comunicação de massa, as tradições musicais orais e comunitárias (...) passaram a ser designadas de música folclórica e o termo música popular passou a distingüir [sic] as práticas musicais veiculadas pela mídia (...) (ULHÔA, 1997, p.80)

Esse mesmo ponto de vista é endossado por outros pesquisadores, dentre os quais, citamos Carlos Sandroni (2004, p.29, grifo do autor):

De fato, no decorrer da década de 1960, as palavras música popular brasileira, usadas sempre juntas como se fossem escritas com traços de união, passaram a designar inequivocadamente as músicas urbanas veiculadas pelo rádio e pelos discos. 
Concordando com Sandroni e Ulhôa, reconhecemos o vínculo inegável da expressão Música Popular Brasileira com um certo grupo de canções, de compositores e de público, mediados pela tecnologia difusora de veículos de comunicação surgidos no século $X X$, com destaque para o rádio e a televisão.

Integram aquele grupo de compositores da MPB os músicos Edu Lobo e Chico Buarque. Em parceria, eles têm uma vasta produção registrada e atuam também como intérpretes, tendo gravado vários discos em suas respectivas carreiras-solo. Nosso objeto de análise, neste breve estudo, é a canção Sobre todas as coisas, gravada no disco 0 grande circo místico, lançado em 1983. Todas as canções desse disco foram compostas por Edu Lobo e Chico Buarque. Enquanto esse assinou os textos verbais, aquele ficou responsável pela criação dos textos musicais.

\section{Aspectos verbais}

Segundo informações contidas no encarte do disco 0 grande circo místico, todas as composições foram inspiradas em poema homônimo de Jorge de Lima, publicado em 1938, no livro A túnica inconsútil. Nesse período de sua vida pessoal, consta que o poeta havia se convertido ao Catolicismo, episódio que impõe certa feição místico-religiosa ${ }^{1}$ a parte da produção literária de Jorge de Lima. Com a intenção de prepararmos a escuta da canção que nos interessa aqui, ampliando a qualidade daquela escuta, leiamos, abaixo, o poema que serviu de mote para a trilha sonora do espetáculo de dança 0 grande circo místico.

\section{Grande Circo Místico}

0 médico de câmara da imperatriz Teresa - Frederico Knieps - resolveu que seu filho também fosse médico,

mas o rapaz fazendo relações com a equilibrista Agnes, com ela se casou, fundando a dinastia de circo Knieps de que tanto se tem ocupado a imprensa.

(5) Charlote, filha de Frederico se casou com o clown, de que nasceram Marie e Oto.

E Oto se casou com Lily Braun a grande deslocadora que tinha no ventre um santo tatuado. A filha de Lily Braun - a tatuada no ventre,

(10) quis entrar para um convento, mas Oto Frederico Knieps não atendeu, e Margarete continuou a dinastia do circo de que tanto se tem ocupado a imprensa. Então, Margarete tatuou o corpo

(15) sofrendo muito por amor de Deus, pois gravou em sua pele rósea a Via-Sacra do Senhor dos Passos. E nenhum tigre a ofendeu jamais: e o leão Nero que já havia comido dois ventriloquos,

(20) quando ela entrava nua pela jaula a dentro, chorava como um recém-nascido. Seu esposo - o trapezista Ludwig - nunca mais a pôde amar, pois as gravuras sagradas afastavam a pele dela e o desejo dêle.

(25) Então, o boxeur Rudolf que era ateu e era homem-fera derrubou Margarete e a violou. Quando acabou, o ateu se converteu, morreu. Margarete pariu duas meninas que são o prodígio do Grande Circo Knieps.

Mas o maior milagre são as suas virgindades
(30) em que os banqueiros e os homens de monóculo têm esbarrado; são as suas levitações que a platéia pensa ser truque; é a sua pureza em que ninguém acredita; são as suas mágicas em que os simples dizem que há o diabo; mas as crianças crêem nelas, são seus fièis, seus amigos, seus devotos.

(35) Marie e Helena se apresentam nuas, dançam no arame e deslocam de tal forma os membros que parece que os membros não são delas. A platéia bisa coxas, bisa seios, bisa sovacos. Marie e Helene se repartem tôdas,

(40) se distribuem pelos homens cínicos, mas ninguém vê as almas que elas conservam puras. E quando atiram os membros para a visão dos homens, atiram as almas para a visão de Deus. Com a verdadeira história do grande circo Knieps

(45) Muito pouco se tem ocupado a imprensa. (LIMA, 1969, p.90)

Segue transcrito o texto verbal da canção Sobre todas as coisas, nosso objeto de estudo.

\section{Sobre todas as coisas}

Pelo amor de Deus

Não vê que isso é pecado, desprezar quem lhe quer bem Não vê que Deus até fica zangado vendo alguém Abandonado pelo amor de Deus

(5) Ao Nosso Senhor

Pergunte se Ele produziu nas trevas o esplendor Se tudo foi criado - o macho, a fêmea, o bicho, a flor Criado para adorar o Criador E se o Criador

(10) Inventou a criatura por favor Se do barro fez alguém com tanto amor Para amar Nosso Senhor Não, Nosso senhor Não há de ter lançado em movimento terra e céu

(15) Estrelas percorrendo o firmamento em carrossel Pra circular em torno ao Criador Ou será que o deus Que criou nosso desejo é tão cruel Mostra os vales onde jorra o leite e o mel

(20) E esses vales são de Deus Pelo amor de Deus Não vê que isso é pecado, desprezar quem lhe quer bem Não vê que Deus fica zangado vendo alguém Abandonado pelo amor de Deus. (BUARQUE; LOBO, 1999, p.165-167)

Tanto no poema de Jorge de Lima quanto no texto verbal da canção de Chico Buarque e Edu Lobo, ainda que na forma de comentário preliminar, destacamos as referências religiosas, presentes nas duas composições. Situamos esse registro, diremos metafísico, de acordo com o que, em nossa cultura, pode ser reconhecido como estando em conformidade com valores do Cristianismo católico. A escolha desse contexto religioso é feita em alusão a fatos da biografia de Jorge de Lima.

Queremos pontuar, também, um outro matiz temático presente no poema e na canção citados: o discurso amoroso. Em Edu Lobo e Chico Buarque, cremos em que é possível, a respeito de Sobre todas as coisas, vê-la como uma unidade discursiva que trata, justamente, do sentimento de amor. Resumidamente, diremos que as palavras da canção expõem um enunciador insatisfeito com a aparente não correspondência de seu interesse amoroso por um outro que é seu objeto de desejo. No poema de Jorge de Lima, o tema amoroso comparece 
sempre, por vezes ornado com ingenuidade e pureza sacras (como exemplo, versos 8, 15, 17), por vezes revelando desvãos menos castos, e talvez, por isso mesmo, igualmente ingênuos, da inscrição erótica do amor (como exemplo, versos 26 e 38). Vale dizer que a interpretação dos versos citados para exemplificar nossos apontamentos não deve ser entendida como limite fixo que bifurca o tema amoroso, fragmentando-o em dois. A flutuação discursiva entre os timbres sagrado e profano, se esses termos são plausíveis aqui, revela um jogo tensivo necessário à participação de ambos os timbres. Dizendo de outro modo, a figuração dual do sentimento de amor, ora metáfora angelical (verso 43), ora imagem maculada (verso 26), traça, na semântica dos versos, um contraste não exclusivista, de coloração sugestivamente barroca. Não estamos falando, portanto, por meio de dicotomias.

Os assuntos encontrados no poema 0 grande circo místico e na canção Sobre todas as coisas sinalizados até aqui, a saber, uma religiosidade de fundo cristão e o sentimento amoroso, presentes em ambas as peças, são o mote que nos levou a procurar um registro anterior, ao qual pudéssemos propor alguma forma de filiação temática. Localizar-nos-emos a partir das escrituras cristãs, consultando uma publicação de 1965 da igreja católica.

0 primeiro dado notório está no fato de a Bíblia Sagrada ser um compêndio de livros que versam sobre uma mitologia religiosa. A respeito desse discurso metafísico e de sua pronúncia segundo uma dicção místico-sensual, isso pode ser visto, de modo exemplar, na concepção humana do Cristo $^{2}$, a segunda pessoa da Trindade. Por meio da participação do metafísico e do físico, representados pelo Espírito Santo e por Maria, respectivamente, divindade e ser humano atuam conjuntamente para que, em sua existência terrena, Cristo seja a própria interseção entre dois mundos, realidades conciliadas na figura de sua

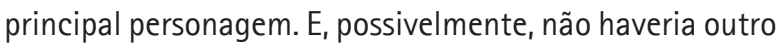
modo de dar à luz um deus feito de organismo e milagres. Cristo, um intervalo conciliador, se não resistíssemos a dar uma definição.

Citamos, a seguir, um excerto bíblico em que, conforme o interpretamos, é possivel estabelecer relações entre religiosidade e sensualidade.

\footnotetext{
10 Que lindos são os teus peitos, irmã minha esposa! Os teus peitos são mais formosos do que o vinho, e o cheiro dos teus bálsamos excede o de todos os aromas.

11 Os teus lábios, ó esposa [sic] são como um favo, que destila doçura, o mel e o leite estão debaixo da tua língua: e o cheiro dos teus vestidos é como o cheiro do incenso

(CÂNTICO DOS CÂNTICOS DE SALOMÃO, 1965, p.520, grifos nossos)
}

Se, como já dissemos, há, no conjunto de textos bíblicos, um contexto nitidamente religioso, por outro lado, cremos em que o fragmento transcrito é enlevado de metáforas sensuais, possibilitando leituras, ao menos, ambíguas. Destacamos, com relação a um comentário comparativo entre o excerto bíblico acima e a canção de Edu Lobo e Chico
Buarque, que há, nas construções metafóricas de ambos os textos, imagens semelhantes, como as que são criadas a partir dos mesmos significantes "leite" e "mel" (conforme verso 19 do texto verbal da canção). Mencionamos, também, o corpo, colocado nos dois textos como marca indelével de sensualidade. Sem a dimensão corpórea, toda figuração erótica teria de ser, necessariamente, sublimada, ou ainda, esvaziada de matéria humana.

No fragmento bíblico, o corpo é explicitamente citado: "peitos, "lábios", "língua", ou sugerido por sensações como o olfato. Aqui, é possível a explicitação, levandose em conta o contexto que molda as palavras: tratase de um livro religioso, em que, jamais, um texto deveria ser lido fora do âmbito do sagrado. Nas notas que acompanham a publicação do texto 0 cântico dos cânticos de Salomão, várias observações são feitas quanto ao significado de certas palavras e expressões, de maneira que as partes anatômicas do corpo humano devem ser lidas como metáforas do amor divino, da própria igreja e de personagens do Cristianismo, como Jesus Cristo e Maria.

Na composição de Edu Lobo e Chico Buarque, temos um discurso de convencimento, um pedido veemente em forma de declaração amorosa. 0 eu-lírico deseja um outro que aparenta não lhe corresponder. Nesse caso, também é evocada a presença divina. É, justamente, em nome de um deus que se deve ceder ao pedido de amor. Mas, ao contrário do texto bíblico, não se trata de amar a Deus, mas de amar por Deus. Parecenos possível sugerir que, à luz da figura intersecional do Cristo, conforme propusemos anteriormente, o enamorado da canção ajusta seu argumento a partir de uma lógica também divinizante, o que não significa dizer que, nos contextos bíblico e cancional, alude-se ao mesmo deus. Esse detalhe determina, substancialmente, a maneira como a corporalidade é manifestada em um e outro casos. Em Sobre todas as coisas, não encontraremos um corpo explícito. Ele está escondido, travestido em barro e vale:

(11) Se do barro fez alguém com tanto amor

(19) Mostra os vales onde jorra o leite e o mel

(BUARQUE; LOBO, 1999, p.165)

A vontade afetiva do enamorado cancional tem um objetivo claro: o encontro com o outro, conjugado na métrica erótica dos corpos. Modulando retoricamente sua fala entre seu interesse pessoal e uma orientação divina - afinal, o abandono a que é submetido aborrece a Deus (verso 3) -, o eu-lírico procura velar o próprio corpo, realidade material perpassada pela instância do erótico. É por Deus que a cessão ao pedido amoroso deve haver por parte de quem é cortejado, mas essa cessão passa ao largo das prescrições religiosas, sobretudo quanto às questões da sexualidade, tão repelida e justificada para fins procriativos pelo Cristianismo católico. Por isso, 
a canção esconde o corpo para falar em nome de um deus, enquanto o texto cristão explicita a matéria. Os respectivos contextos pretendem estabelecer os limites da função corporal. Dizendo de outro modo, fica a sugestão de que não é o corpo, significante da parábola e da canção, que deve ser lido, e sim o contexto, autor da grafia que empresta sentido ao corpóreo.

Perguntamos: a que serve a pronúncia divinizada do enunciador apaixonado de Sobre todas as coisas? Arriscamos uma resposta: à afirmação de um desejo de vales de leite e mel em que apenas "macho" e "fêmea" podem ser protagonistas. Quanto mais o eu-lírico da canção entoa sua vontade amorosa, mais pronuncia o nome divino - os significantes "Deus", "Nosso Senhor", "Criador" e "Ele" são revezados em 15 dos 24 versos do texto verbal da canção, além de trechos dos quais alguns desses significantes participam por meio de elisão -, mais subverte a tábua de valores cristãos.

Aqui, à medida que fala, o enamorado despe seu interesse: "deus ama com o falo", diz ele, deixando à mostra um ventre de santo tatuado escorrendo a claridade láctea de uma outra missa. E a liturgia dessa vontade inadiável, redizemos, é fala e falo. Escrito em segunda pessoa, o texto verbal da canção faz da linguagem seu principal fetiche, superfície tátil:

\begin{abstract}
A linguagem é uma pele: esfrego minha linguagem no outro. É como se eu tivesse palavras ao invés de dedos, ou dedos na ponta das palavras. Minha linguagem treme de desejo. A emoção de um duplo contacto: de um lado, toda uma atividade do discurso vem, discretamente, indiretamente, colocar em evidência um significado único que é "eu te desejo", e liberá-lo, alimentá-lo, ramificá-lo, fazê-lo explodir (a linguagem goza de se tocar a si mesma); por outro lado, envolvo o outro nas minhas palavras, eu 0 acaricio, o roço, prolongo esse roçar, me esforço em fazer durar o comentário ao qual submeto a relação (BARTHES, 1985, p.64).
\end{abstract}

Ainda inspirados por Barthes, propomos reconstruir a frase em que esse autor diz ser, o coração, "Um órgão erétil". Em Sobre todas as coisas, o verbo é o órgão erétil, órgão do desejo. Nesse sentido, falar é por em curso uma voluptuosa trama de palavras e dedos. E temos, novamente, um indício de que a divindade cancional é bem diversa do deus cristão. Conforme prescreve a tábua normativa do Cristianismo, não é permitido que o nome divino seja pronunciado em vão. Em outra passagem bíblica, o próprio Cristo diz haver o mal no que sai e não no que entra pela boca do homem. Nos dois exemplos, a mesma regra: sê cuidadoso e casto com a linguagem, matéria ofídea ${ }^{3}$ em que há, ou pode haver, perdição. Refinada e irônica a sutileza de que se vale o eu-lírico de Sobre todas as coisas, ao articular sensualidade e divindade por meio da linguagem. Notemos, não mudam as cartas e a jogada, mudam as regras.

\section{Aspectos musicais}

Interessa-nos, nesse ponto de nossa argumentação, perceber que correspondências é possivel apontar entre os textos verbal e musical da canção de Edu Lobo e Chico Buarque.
Adotaremos um sistema analítico proposto por Luiz Tatit. Valendo-se de material teórico da Semiótica, Tatit criou um modo próprio de distribuir os textos verbais das canções, considerando a posição melódica das sílabas verbais na articulação das alturas, em notação paralela ao modo tradicional de escrita musical. Antes da apresentação dos diagramas, algumas observações. Primeiramente, é importante observar que cada camada horizontal corresponde a um intervalo melódico diatônico, ou seja, os intervalos representados compõem a escala da tonalidade da canção. No caso de haver acidentes intervalares, eles serão apontados juntamente com as sílabas verbais correspondentes. A cada segmento corresponde um verso do texto verbal da canção. Feitas essas considerações, vejamos os primeiros segmentos de Sobre todas as coisas no Ex.1.
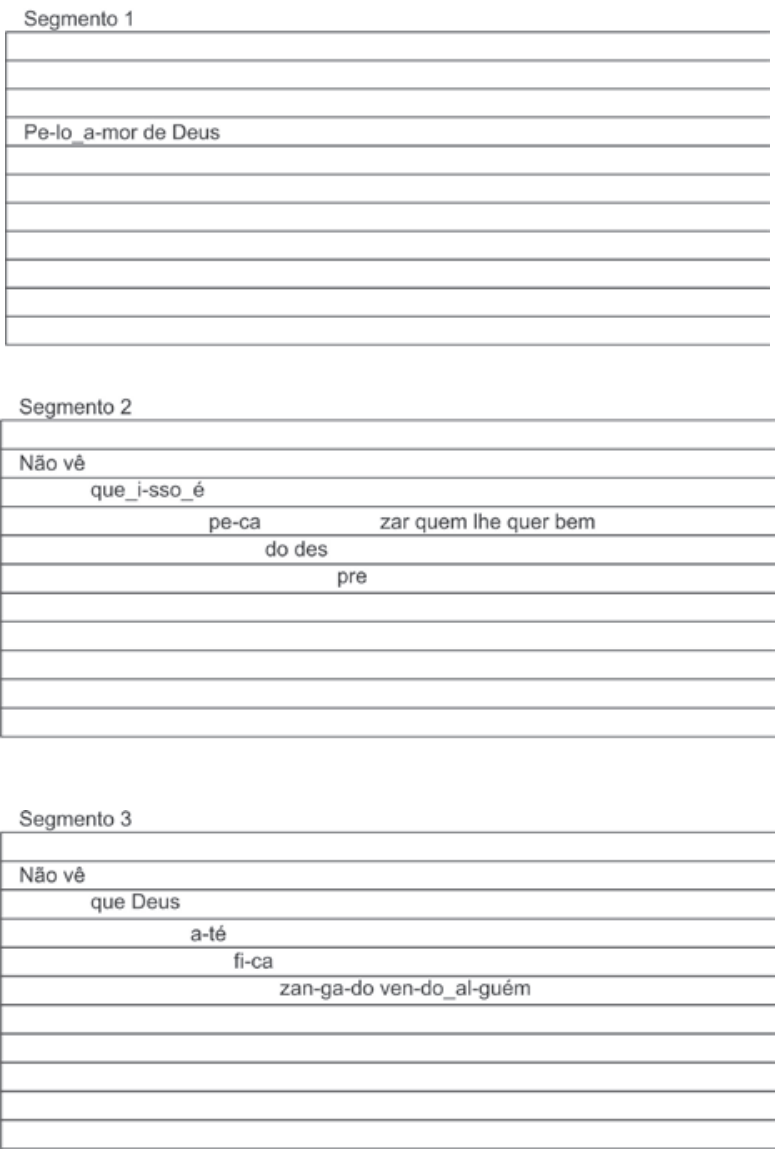

Segmento 4

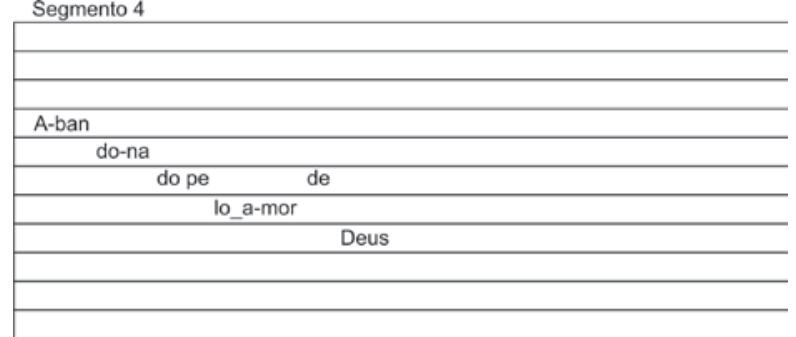

Ex.1 - Diagramas verbo-melódicos correspondentes aos versos 1, 23 e 4 do texto verbal da canção. 
Os quatro primeiros segmentos correspondem à primeira parte do conteúdo melódico, que será repetido nos segmentos de 5 a 8 , com mudança do texto verbal. Já nesses primeiros segmentos, vemos duas tendências que permanecem ao longo da canção. De um lado, temos uma tentativa de sustentação melódica, como vemos no segmento 1. Com o início da melodia em um intervalo de quinta ascendente, chegando a um intervalo de sétima ascendente no início do segmento 2 , a tessitura melódica é elevada, favorecendo o que Tatit chama de modalidade do/ser/, a partir da qual a canção é um convite a estados internos de subjetividade, propícios a que o eu-lírico exponha seus sentimentos. Nesses casos, é comum que o registro verbal apresente uma história narrada sob a égide da disforia, em que a perda de algo ou alguém é lamentada. Está em processo a passionalização melódica, sobre a qual diz Tatit (2002, p.10):

\begin{abstract}
A ampliação da freqüência e da duração valoriza a sonoridade das vogais, tornando a melodia mais lenta e contínua [...] Daqui nasce a paixão que, em geral, já vem relatada na narrativa do texto [verbal]. Por isso, a passionalização melódica é um campo sonoro propício às tensões ocasionadas pela desunião amorosa ou pelo sentimento de falta de um objeto de desejo.
\end{abstract}

Entretanto, aos gestos de elevação e sustentação melódicas contrapõe-se a outra tendência de que falávamos anteriormente, percebida na curva descendente observada nos segmentos 2, 3 e 4. Aqui, aparecem os traços entoativos da fala - lembremo-nos de que se trata de um texto verbal escrito em segunda pessoa, fundamentalmente dialógico, portanto, embora apenas um enunciador pronuncie, no caso da canção em estudo -. A expressividade coloquial da fala prevalece, relaxando a tensão da elevação melódica e valorizando o contorno descendente característico de frases assertivas. Esse processo Tatit classifica como figurativização, em que "[...] imperam as leis de articulação linguística, de modo que compreendemos o que é dito [melodicamente] pelos mesmos recursos utilizados no colóquio" (TATIT, 2002, p.21).

Parece-nos importante observar que, se no nível melódico, as alturas são, aos poucos, reduzidas, isso não é suficiente para anular o projeto entoativo da canção, orientado pelo interesse afetivo do eu-lírico - modalidade do /ser/. As sucessivas contraposições entre as sustentações e as descendências melódicas dos primeiros segmentos indiciam, em um estrato mais profundo, a carga emotiva da cena descrita. Vejamos. Movido pela necessidade de conjunção com o outro, seu objeto de desejo, resultado pretendido no manejo retórico de um discurso místicosensual, o enamorado de Sobre todas as coisas busca o equilíbrio entre a insistência do convite amoroso, sempre reiterado - como as sílabas verbais insistentemente articuladas em um mesmo intervalo melódico (de quinta ascendente nos segmentos 1 e 2 e de terça ascendente no segmento 3) -, e a paciência da expectativa pelo consentimento do outro, procurando a temperança do sentimento na melodia descendente da fala. Em outras palavras, essa descendência parece manifestar o gesto metonímico de, por meio da fala, corpo sonoro - pele do desejo, dirá Barthes - ser buscado um autocontrole somático por parte do amante, regrando a necessidade, sempre urgente, de conjunção com o outro, corpo amado. Seja como for, nas duas circunstâncias - sustentação e descendência melódicas -, a espera angustiada de todo apaixonado. Ainda Barthes (1985, p.94, grifo do autor): "A identidade fatal do enamorado não é outra senão: sou aquele que espera".

Prossigamos na observação dos segmentos no Ex.2. Os segmentos de 5 a 8, como já dissemos, retomam o mesmo caminho melódico dos quatro segmentos anteriores. Ficam valendo, assim, as observações já feitas para a primeira parte desse trecho da melodia. No plano verbal, é mantida a estratégia de convencimento do outro.
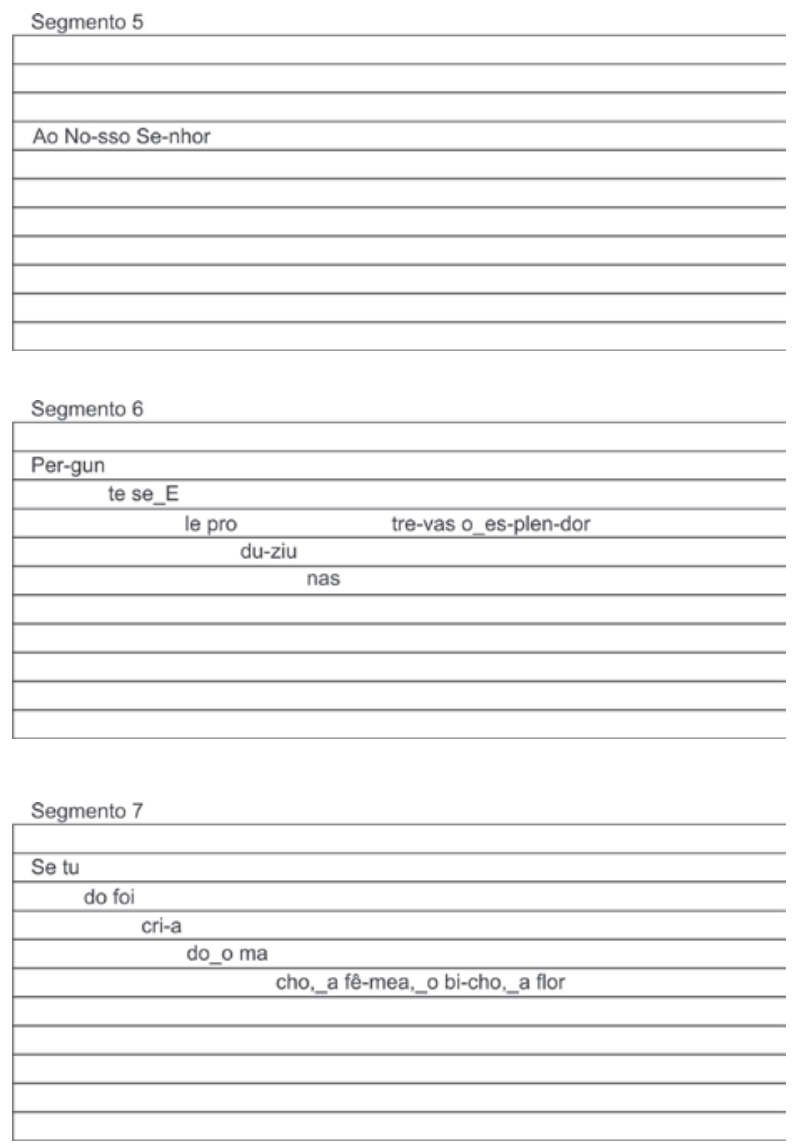

Segmento 8

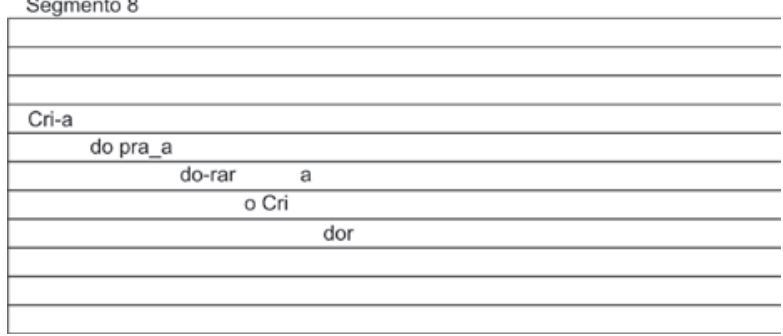

Ex.2 - Diagramas verbo-melódicos correspondentes aos versos 5, 6, 7 e 8 do texto verbal da canção. 
Pontuamos, ainda, um dado. Notemos que nos dois blocos verbo-melódicos da primeira parte da canção (segmentos de 1 a 4 e segmentos de 5 a 8), os trechos de sustentação melódica articulam intervalos de quinta e de terça ascendentes. Se acrescentamos a esses o intervalo de tônica, articulado nos segmentos que encerram os blocos, a saber, o 4 e o 8, formamos a tríade - conjunto de três sons básicos - do acorde de I grau da tonalidade. Ao consultarmos a partitura de Sobre todas as coisas editada por Almir Chediak ${ }^{4}$, vemos que nos compassos em que há as sustentações, estão indicados, quase que exclusivamente, acordes do I grau da tonalidade, construindo uma base melódico-harmônica muito coesa, favorável a que o chamado amoroso seja ouvido sem dissonâncias, ou desconforto, se preferirmos, por quem é cortejado. Verificando o contexto harmônico da primeira parte da canção, encontramos, também, ocorrências do acorde de dominante do I grau - G7(b9) -, o que nos permite, além de perceber a pouca variação de acordes, gravitando, em geral, em torno do acorde de I grau, reconhecer um processo amplo de reiterações que se dão nos níveis verbal, melódico e harmônico.

Vejamos, a seguir, no Ex.3, a segunda parte da canção, com sensível mudança do material musical.

Abrindo a segunda parte da canção, o segmento 9, assim como os que iniciaram os blocos verbo-melódicos anteriores (segmentos 1 e 5), articula sílabas verbais em um único intervalo melódico. Trata-se, aqui, do ponto de maior tensão em Sobre todas as coisas, com a articulação do intervalo de oitava, inédito até esse momento, atingindo o ponto mais alto da tessitura melódica. Nos segmentos 10, 11 e 12, o contorno ascendente da melodia parece tentar manter o projeto entoativo na via passional. Sobre os trechos - ou tonemas, no dizer de Tatit - ascendentes, eles podem sugerir uma "[...] prorrogação das incertezas ou das tensões emotivas de toda sorte" (TATIT, 2002, p.22). De fato, o eu-lírico segue em seu discurso amoroso, sem que haja qualquer sinalização de êxito na trajetória de seu objetivo sentimental. Dizendo de outro modo, o enamorado continua pontuando sua paixão, ao mesmo tempo em que espera que ela seja consumada no movimento conjuntivo do encontro com o outro. Embora a construção cancional, nesse trecho, seja mantida segundo aspectos da modalidade do /ser/, devemos observar uma curiosa inversão de relações. Se, na primeira parte da canção, as sustentações melódicas respondiam pela ênfase do registro passional, em constante revezamento com tonemas descendentes cuja atuação definia uma tentativa de equilíbrio emotivo por parte do eu-lírico, as reiterações intervalares dos segmentos 10 e 11, abaixo do pico melódico de seus respectivos segmentos, parecem compor o contrapeso dos tonemas ascendentes. Além da identificação verbo-sonora, é possível traçar um caminho descendente ao relacionarmos as palavras "favor", "amor" e "Senhor" - ainda que, na articulação dessa última, não haja reiteração por intervalos melódicos seguidos -, articuladas em intervalos de V, IV e III graus, respectivamente, parecendo inocular o caráter entoativo da fala na melodia amorosa da paixão. Como já dissemos, Sobre todas as coisas expõe o conflito emotivo de um enamorado a meio passo entre a entrega passional e a temperança, entre sua necessidade conjuntiva e a realidade, até o momento, disjuntiva. Se preferirmos, entre o falo e a fala.

No tocante à harmonia da segunda parte da canção, ela é desenvolvida segundo progressões que estabelecem bastante coesão. Inicialmente, temos uma progressão harmônica classificada como II Cadencial Secundário ${ }^{5}$ $(\mathrm{Ilm} 7 \rightarrow \mathrm{V} 7 / \mathrm{IV} \rightarrow \mathrm{IV} 7 \mathrm{M})$, seguida de relações de dominante e substituto da dominante (SubV7) que avançam em acordes formados a partir de intervalos de $\mathrm{V}$ grau ascendente, até que a harmonia retorne ao acorde de I grau. A construção harmônica da canção, portanto, parece configurar um campo reconhecido e neutro a partir do qual os embates verbo-melódicos são travados.

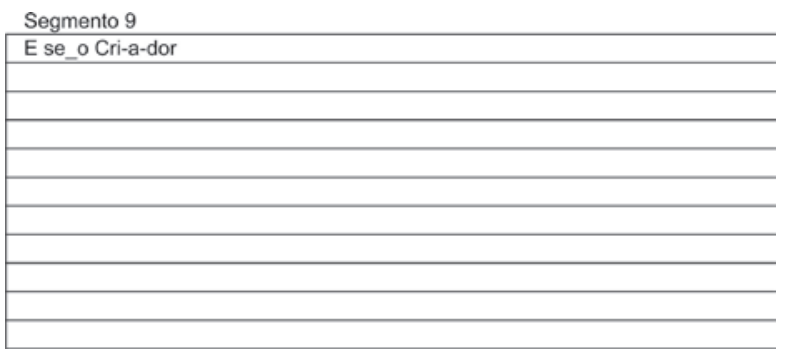

Segmento 10

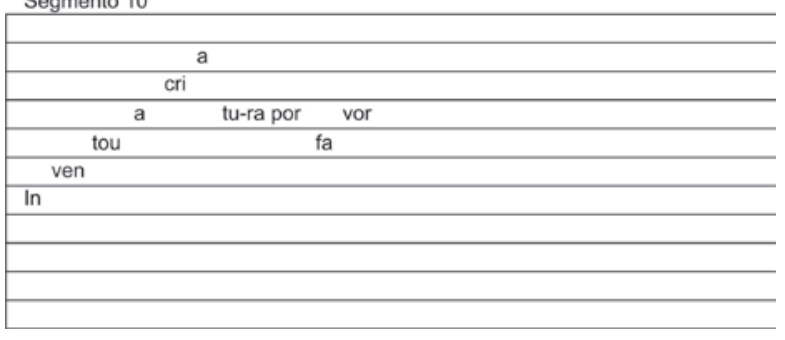

Segmento 11

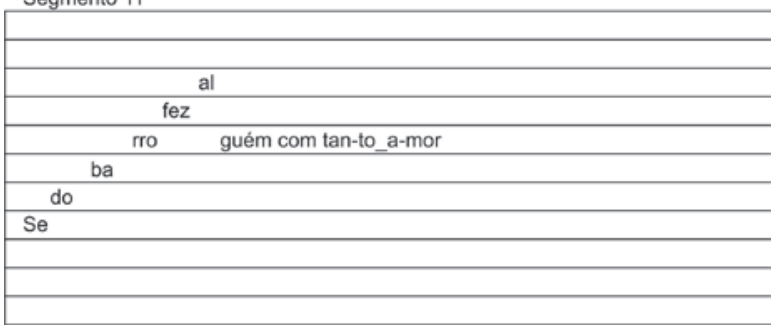

Segmento 12

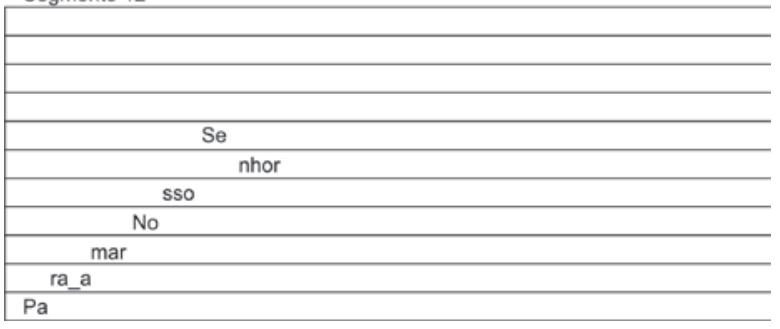

Ex.3 - Diagramas verbo-melódicos correspondentes aos versos $9,10,11$ e 12 do texto verbal da canção. 
Na sequência, a canção voltará à primeira parte (conforme contorno melódico dos segmentos de 1 a 4), à segunda parte (conforme contorno melódico dos segmentos de 9 a 12), finalizando com a primeira parte, novamente. Nesse percurso, muda o texto verbal, embora seu conteúdo mantenha a retórica amorosa do eu-lírico. Apenas na última passagem pela primeira parte da canção, os versos articulados são repetidos, correspondendo aos primeiros quatro versos do texto verbal. Com isso, a estrutura cancional recompõe, ao final, a exortação feita pelo enamorado anteriormente, sendo mantida a expectativa de uma resposta por parte de quem é cortejado.

\section{Conclusão}

Sobre todas as coisas já recebeu interpretação de vários artistas da Música Popular Brasileira. A versão original é de Gilberto Gil, seguida de leituras individuais dos próprios autores, Edu Lobo e Chico Buarque, de Zizi Possi, além de um registro recente feito pela cantora Maria Rita. Em cada nova versão, são lançados olhares de ângulos diferentes, mas que convergem sempre para o mesmo ponto, em que nos deparamos com um enamorado ungido de sentimento e sensualidade, entoando geografias de barro e mel, vontades adiadas pela aparente não correspondência do outro.

Equilibrado entre o arroubo do desejo e a moderação da espera, o interesse passional é definido por um limite sutil, corredor estreito em que o eu-lírico prostra-se para declinar seu rosário amoroso cujo preceito maior afirma que é preciso amar - por Deus, já dissemos - "sobre todas as coisas". Se a prece do enamorado garante a conjunção pretendida, isso não é sabido, mas o espaço divinamente sensual da canção permite que a conjunção seja, ao menos, entoada.

\section{Referências}

BUARQUE, Chico; LOBO, Edu. O grande circo místico. Rio de Janeiro: Som Livre, 1983 (CD 11-v005, remasterizado). Sobre todas as coisas [partitura]. In: CHEDIAK, Almir. Songbook Chico Buarque - vol. III. 3 ed. Rio de Janeiro: Lumiar, 1999, p.165-167.

CÂNTICO DOS CÂNTICOS DE SALOMÃO. In: Bíblia Sagrada. Tradução de padre Antônio Pereira de Figueiredo. Notas de mons. José Alberto de Castro Pinto. Rio de Janeiro: Edição Barsa, 1965.

CHEDIAK, Almir. Harmonia e improvisação. 16 ed. Rio de Janeiro: Lumiar Editora, s.d.

FARACO, Carlos E.; MOURA, Francisco Marto de. Literatura brasileira. 10 ed. São Paulo: Ática, 1994.

LIMA, Jorge de. Antologia poética. Rio de Janeiro: Sabiá, 1969.

PLATÃO. O Banquete - Apologia de Sócrates. Tradução de Carlos Alberto Nunes. 2 ed. rev. Belém: EDUFPA, 2001.

SANDRONI, Carlos. Adeus à MPB. In: Decantando a república: inventário histórico e político da canção popular moderna brasileira. CAVALCANTE, Berenice; STARLING, Heloisa M. M.; EISENBERG, José (org.). Rio de Janeiro: Nova Fronteira; São Paulo: Fundação Perseu Abramo, 2004. (Vol 1)

TATIT, Luiz. O cancionista: composição de canções no Brasil. 2 ed. São Paulo: EDUSP, 2002.

ULHÔA, Martha Tupinambá de. Nova história, velhos sons: notas para ouvir e pensar a música brasileira popular. In: Debates, vol. 01. Rio de Janeiro: CLA/Unirio, 1997, p.80-99.

\section{Notas}

${ }^{1}$ FARACO, Carlos E.; MOURA, Francisco Marto de. Literatura brasileira. 10 ed. São Paulo: Ática, 1994, p.240.

${ }^{2}$ A carga de sensualidade, nesse caso, pode ser situada no dado físico da concepção terrena de Cristo, já que a procriação humana, como sabemos, somente é possivel por meio de relações sexuais.

${ }^{3}$ Além da alusão evidente à serpente do paraíso original cristão, vale citar Alcibiades, o enamorado platônico do Banquete, sobre seu encantamento por Sócrates: "[...] meu caso é igual ao do indivíduo mordido de cobra [...]" (PLATÃO, 2001, p.85).

${ }^{4}$ BUARQUE, Chico; LOBO, Edu. Sobre todas as coisas [partitura]. In: CHEDIAK, Almir. Songbook Chico Buarque - vol. III. 3 ed. Rio de Janeiro: Lumiar, 1999. p.165-167.

${ }^{5}$ CHEDIAK, Almir. Harmonia e improvisação. 16ed. Rio de Janeiro: Lumiar Editora, s.d., p.101. (Vol I).

Márcio Ronei Cravo Soares é Mestre em Música (UFMG) e Licenciado em Letras-Português (UFES). Atua como professor universitário em faculdades particulares de Belo Horizonte, ministrando disciplinas voltadas para a produção e a interpretação de textos. Participa de formações de música popular (Jazz, MPB e Rock), como contrabaixista e violonista. Radialista, trabalha como Locutor na Rede Inconfidência de Rádio, órgão vinculado à Secretaria de Estado de Cultura de Minas Gerais. Possui contos e poemas publicados em antologias. Possui artigos acadêmicos publicados nas áreas de Música, Literatura e Linguística. 